
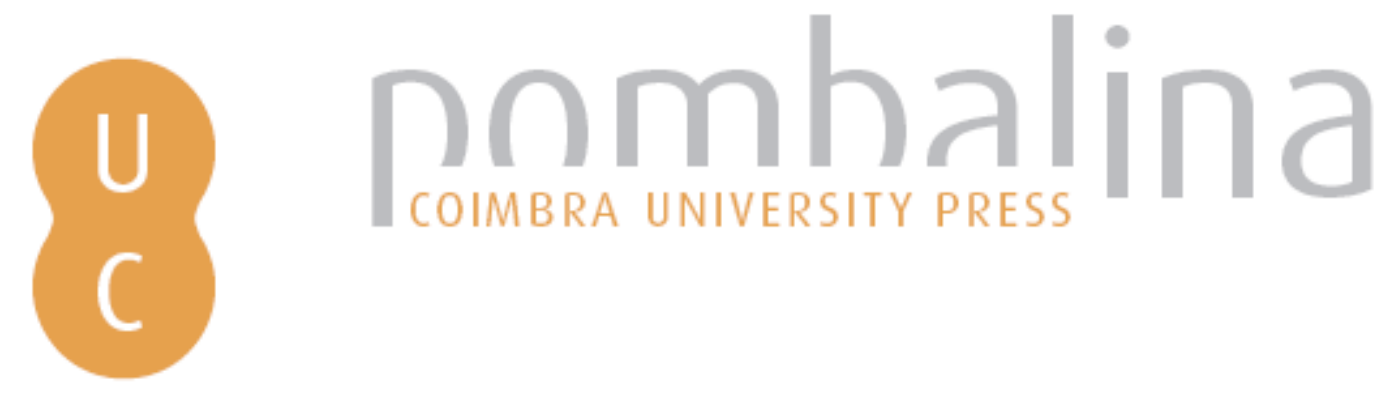

\title{
Transition to Higher Education: lifestyle changes, health condition and academic success of first-year students
}

Autor(es): $\quad$ Soares, Andreia; Pereira, Marco; Canavarro, José

Publicado por: Imprensa da Universidade de Coimbra

URL

persistente: URI:http://hdl.handle.net/10316.2/38618

DOI: $\quad$ DOI:http://dx.doi.org/10.14195/978-989-26-0775-7_14

Accessed : $\quad$ 26-Apr-2023 12:43:33

A navegação consulta e descarregamento dos títulos inseridos nas Bibliotecas Digitais UC Digitalis, UC Pombalina e UC Impactum, pressupõem a aceitação plena e sem reservas dos Termos e Condições de Uso destas Bibliotecas Digitais, disponíveis em https://digitalis.uc.pt/pt-pt/termos.

Conforme exposto nos referidos Termos e Condições de Uso, o descarregamento de títulos de acesso restrito requer uma licença válida de autorização devendo o utilizador aceder ao(s) documento(s) a partir de um endereço de IP da instituição detentora da supramencionada licença.

Ao utilizador é apenas permitido o descarregamento para uso pessoal, pelo que o emprego do(s) título(s) descarregado(s) para outro fim, designadamente comercial, carece de autorização do respetivo autor ou editor da obra.

Na medida em que todas as obras da UC Digitalis se encontram protegidas pelo Código do Direito de Autor e Direitos Conexos e demais legislação aplicável, toda a cópia, parcial ou total, deste documento, nos casos em que é legalmente admitida, deverá conter ou fazer-se acompanhar por este aviso.

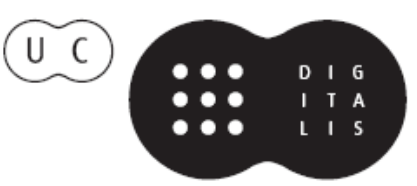




\section{INTERNATIONAL \\ STUDIES IN TIME \\ PERSPECTIVE}

MARIA PAULA PAIXÃO

JOSÉ TOMÁS DA SILVA

(COORD.)

VICTOR ORTUÑO

PEDRO CORDEIRO

(EDITORS)

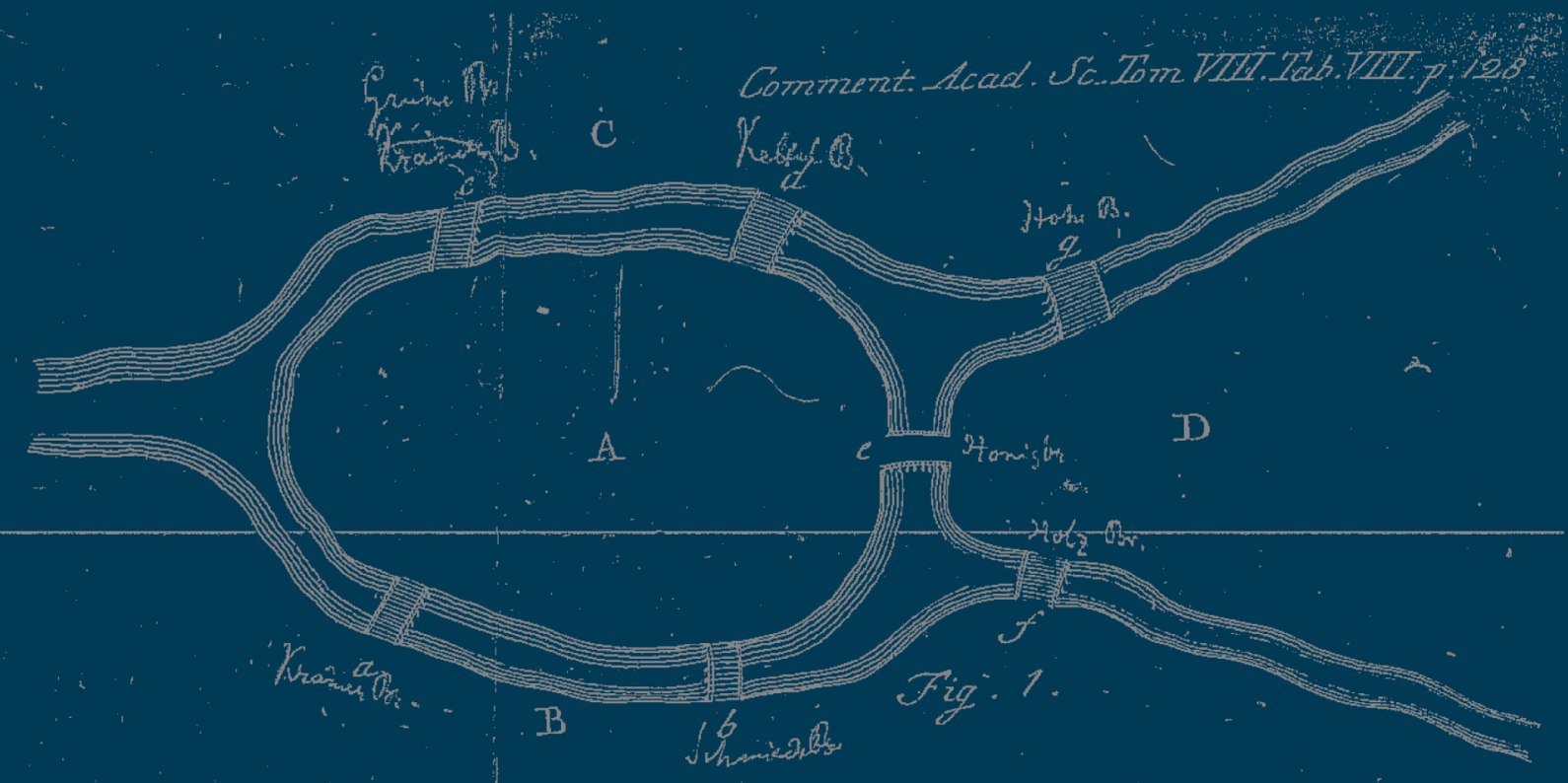

IMPRENSA DA

UNIVERSIDADE

DE COIMBRA

COIMBRA

UNIVERSITY

PRESS 


\title{
Chapter 14 \\ TRANSITION TO HIGHER EDUCATION: LIFESTYLE CHANGES, HEALTH CONDITION AND ACADEMIC SUCCESS OF FIRST-YEAR STUDENTS
}

\author{
Andreia Soares \\ Marco Pereira \\ José Canavarro \\ Faculty of Psychology and Educational Sciences, University of Coimbra, Portugal \\ andreiamsoares2@gmail.com
}

AвSTRACT: Lifetime normative transitions, which include significant ecological structural changes, as transition to higher education, constitute a risk factor in the adoption and maintenance of healthy lifestyles. Health behaviours and attitudes (HBA) that integrate personal lifestyle are variables that influence students' health condition and academic success. Objectives and sample: A sample of firstyear students $(N=546)$ from the University of Coimbra, from the academic year 2009/2010, was collected in order to study "students in transition" (1) perception of occurred and desirable changes in seven HBA sets of their lifestyle and its impact perceived in subjects overall health, adaptation process and academic performance; (2) actual health condition and academic success; and (3) the influence of some HBA on these variables. Main results: Although the prevalence of HBA has changed with transition, most of the students have changed/maintained a healthy lifestyle, except for alcohol consumption and physical/sports activity. These two HBA played an important and conflicting role in health condition, as well as in academic success. Conclusions: Most of the results are consistent with the literature and provided important information for planning a health and academic success promotion intervention project in this specific context.

Keywords: academic success, health condition, health behaviours/attitudes, higher education, transition.

\section{INTRODUCTION}

Transition periods represent always, regardless of when they occur in lifespan, (the perception of) instability or discontinuity and adjustment, which requires in most cases changes in patterns of behavioural, cognitive and emotional responses (Almeida, Soares \& Ferreira, 2000; Reich, Harber \& Siegel, 2008) and mobilization of available resources (Seabra, 2007). Transition to higher education appears to be a specific process that falls within transition processes in general, in a transitional perspective (Pinheiro, 2004), and is often experienced by students as the most desired but simultaneously difficult process, because of educational, ecological and developmental changes involved in it (Pinheiro, 2004; Pittman \& Richmond, 2008). While most students are able to cope with the diversity of changes and to succeed in adaptation/adjustment process (or in transition process answer), others students experience (psychological, emotional, physical or social) health problems, 
that may compromise not only health condition (level of health of an individual, family or community at a given point in time, which can be assessed either by objective indicators or by more subjective measures; Fleck, 2008), but also academic success (here understood as a broader concept than academic performance or retention rate; thus, its assessment also includes personal, educational, social and vocational experiences of students; Upcraft, Gardner, Barefoot \& Associados, 2005) and precipitate studies interruption or cessation, during or at the end of the academic year (DeBerard, Spielmans \& Julka, 2004; Rayle \& Chung, 2008).

During the past two decades, health-related behaviours and attitudes or HBA (set of actions and relatively enduring organizations of beliefs, feelings and behavioural tendencies usually grouped into two broad categories, based on their impact on health: (1) positive HBA, such as tobacco abstinence, physical/sports activity or others which may protect or optimize health condition, and (2) negative HBA, such as excessive alcohol consumption, poor sleep hygiene, among others which may be damaging to health condition; Odgen, 2004) that integrate personal lifestyle of higher education students have been widely investigated, for purposes as epidemiological reasons, behaviour predictors studies (the investigation carried out by Wardle and Steptoe, since 1989, is a paradigmatic example), relationship between those variables and health/disease related variables (well-being, quality of life, stress, etc.; cf., p.e., Dusselier, Dunn, Wang, Shelley II \& Whalen, 2005; Grant, Wardle \& Steptoe, 2009; Seabra, 2007) or academic success (cf., p.e., DeBerard, Spielmans \& Julka, 2004; Elias, Azevedo \& Maia, 2009) analyses. Although most of the young adults in tertiary education do not present negative HBA, some researchers call attention to the role of the adaptation process to higher education in the acquisition of unhealthy habits: psychoactive substances use or insufficient sleep can result from (1) stress induced by multiple changes (growing responsibility and autonomy in their personal and academic experiences, for instance) and by assessment periods (Dusselier et al., 2005) or (2) social intercourse with peers with unhealthy personal lifestyles, while parental monitoring decreases (Precioso, 2004). In general, a healthy lifestyle (in particular, an adequate sleep pattern, regular exercise that doesn't steal time from academic tasks, or absence of excessive consumption of alcohol and tobacco) provides higher levels of health and well-being (Vaez \& Laflamme, 2003) and academic performance (DeBerard, Spielmans \& Julka, 2004; Elias, Azevedo \& Maia, 2009; Trockel, Barnes \& Egget, 2000), as well as academic success, life satisfaction and absence of stress inducers have been found to predict the avoidance of negative HBA and the expression of HBA positive to students' health (Grant, Wardle \& Steptoe, 2009).

\section{Method}

\section{Sample}

546 first-year students from the academic year 2009/2010 were recruited from all 8 faculties of the University of Coimbra. Mean age of participants was 18.7 $(S D=1.0)$, with the youngest participant being 17 years old and the oldest 24 years old. Women constituted $58 \%$ of the sample. The majority of the participants was Portuguese $(96 \%$; $72 \%$ had left home to attend university), single (100\%) and from average (45\%) and low (34\%) socioeconomic levels. 


\section{Procedure}

All participants received information about the purpose and content of this crosssectional study and they gave informed consent about voluntary participation. Full confidentiality was guaranteed. Implementation of the evaluation protocol took place from March to May of 2010, inside the University of Coimbra classrooms.

Measures: An anonymous self-report questionnaire was developed to assess (a) sociodemographic characteristics, (b) prevalence of seven HBA sets before and after entering university (these questionnaire items were developed based on existing assessment instruments, such as Health and Behaviour Survey; Grant, Wardle \& Steptoe, 2009), (c) direction of possible changes in all HBA considered, taking into account the potential impact on students' health, (d) students' perception of the impact of these possible changes on their health, adaptation process and academic performance and students' desire about HBA changes, (e) subjects' perception of their actual general health condition and (f) academic performance (it was given by the weighted average of students' examination results of the first semester). The short form of another questionnaire (QVA-r or Questionário de Vivências Académicas - versão reduzida; Almeida, Soares \& Ferreira, 2000) was used to measure personal, educational, social and vocational experiences considered to have strong repercussions on the quality of adaptation/adjustment to higher education. More details about these 2 questionnaires can be found elsewhere (Soares, Pereira \& Canavarro, in press).

Data analysis: The data were analyzed using SPSS version 17.0. Statistical analyses used were descriptive statistics, paired Student's t-test and Spearman's rank correlation coefficient.

\section{Results}

Table 1 shows the prevalence of HBA before and after entering university and the sample distribution by the four categories of the variable "direction of possible changes in HBA": HBA positive change (PC), HBA negative change (NC), HBA positive non-change $(\mathrm{PnC})$ and $\mathrm{HBA}$ negative non-change $(\mathrm{NnC})$.

Table 1 - Prevalence of HBA before and after entering university and sample distribution by "direction of possible changes in HBA" categories.

\begin{tabular}{|c|c|c|c|c|}
\hline \multirow{3}{*}{ HBA } & \multirow{2}{*}{\multicolumn{2}{|c|}{$\begin{array}{l}\text { Prevalence of HBA }(N=546) \\
M \pm S D(\text { Min-Max }) \text { or } \%(n)\end{array}$}} & \multirow{2}{*}{\multicolumn{2}{|c|}{$\begin{array}{l}\text { Direction of possible changes in } \\
\text { HBA }(N=546)\end{array}$}} \\
\hline & & & & \\
\hline & Before university & In university & \multicolumn{2}{|c|}{$\%(n)$} \\
\hline \multicolumn{5}{|l|}{ Eating behaviour } \\
\hline \multirow{2}{*}{ Meals (per day) } & \multirow{2}{*}{$4.3 \pm 0.8(2-8)$} & \multirow{2}{*}{$4.1 \pm 1.0(2-12)$} & NnC 5.9 (32) & NC 17.8 (97) \\
\hline & & & PC 11.7 (64) & PnC 64.7 (353) \\
\hline \multirow{2}{*}{$\begin{array}{l}\text { Nutritional quality of } \\
\text { meals }\end{array}$} & Poor: 4.4 (24) & Poor: $13.2(72)$ & $\mathrm{NnC} 3.5$ (19) & NC 9.7 (53) \\
\hline & $\begin{array}{l}\text { Satisf: } 24.9 \text { (136) } \\
\text { Good: } 70.7 \text { (386) }\end{array}$ & $\begin{array}{l}\text { Satisf: } 56.8(310) \\
\text { Good: } 30.0(164)\end{array}$ & PC 48.0 (262) & PnC 38.8 (212) \\
\hline
\end{tabular}




\begin{tabular}{|c|c|c|c|c|}
\hline \multirow{3}{*}{ HBA } & \multirow{2}{*}{\multicolumn{2}{|c|}{$\begin{array}{l}\text { Prevalence of HBA }(N=546) \\
M \pm S D(\text { Min-Max) or } \%(n)\end{array}$}} & \multirow{3}{*}{\multicolumn{2}{|c|}{$\begin{array}{l}\text { Direction of possible changes in } \\
\text { HBA }(N=546) \\
\%(n)\end{array}$}} \\
\hline & & & & \\
\hline & Before university & In university & & \\
\hline \multirow{2}{*}{$\begin{array}{l}\text { Sleep-wake pattern } \\
\text { Hours of sleep (per day) }\end{array}$} & & & & \\
\hline & $8.1 \pm 1.2(2-13)$ & $7.0 \pm 1.2(1-12)$ & $\begin{array}{l}\mathrm{NnC} 5.5(30) \\
\mathrm{PC} 33.2(181)\end{array}$ & $\begin{array}{l}\text { NC } 33.0(180) \\
\text { PnC } 28.4(155)\end{array}$ \\
\hline Quality of sleep & $\begin{array}{l}\text { Poor: } 2.2(12) \\
\text { Satisf: } 29.9(163) \\
\text { Good: } 67.9(371) \\
\end{array}$ & $\begin{array}{l}\text { Poor: } 15.0(82) \\
\text { Satisf: } 54.0(295) \\
\text { Good: } 31.0(169)\end{array}$ & $\begin{array}{l}\mathrm{NnC} 1.8(10) \\
\text { PC } 34.8(190)\end{array}$ & $\begin{array}{l}\text { NC } 13.2(72) \\
\text { PnC } 50.2(274)\end{array}$ \\
\hline \multicolumn{5}{|l|}{$\begin{array}{l}\text { Physical/sports activity } \\
\text { pattern }\end{array}$} \\
\hline $\begin{array}{l}\text { Frequency of physical/ } \\
\text { sports activity practice } \\
\text { (per week) }\end{array}$ & $\begin{array}{c}\text { Rare: } 9.7(53) \\
\text { Occas: } 29.5(161) \\
\text { Often: } 60.8(332)\end{array}$ & $\begin{array}{l}\text { Rare: } 39.9(218) \\
\text { Occas: } 37.4(204) \\
\text { Often: } 22.7(124)\end{array}$ & $\mathrm{NnC} 14.5$ (79) & $\begin{array}{l}\text { NC } 62.8(343) \\
\operatorname{PnC} 11.7(64)\end{array}$ \\
\hline \multicolumn{5}{|l|}{$\begin{array}{l}\text { Psychoactive substances } \\
\text { consumption }\end{array}$} \\
\hline Illicit drugs consumption & $\begin{array}{l}\text { Never: } 88.3(482) \\
\text { Rare: } 7.5(41) \\
\text { Occas: } 2.9(16) \\
\text { Often: } 1.3(7)\end{array}$ & $\begin{array}{l}\text { Never: } 88.6(484) \\
\text { Rare } 6.0(33) \\
\text { Occas: } 3.3(18) \\
\text { Often: } 2.0(11)\end{array}$ & NnC 8.1 (44) & $\begin{array}{c}\text { NC } 3.3(18) \\
\text { PnC } 88.1(481)\end{array}$ \\
\hline $\begin{array}{l}\text { Alcohol consumption } \\
\text { (units per day) }\end{array}$ & $0.3 \pm 0.8(0-5)$ & $0.8 \pm 1.4(0-10)$ & $\begin{array}{l}\mathrm{NnC} 1.1(6) \\
\mathrm{PC} 16.3(89)\end{array}$ & $\begin{array}{c}\text { NC } 10.3(56) \\
\text { PnC } 72.3(395)\end{array}$ \\
\hline $\begin{array}{l}\text { Excessive alcohol (> } 20 \mathrm{~g} / \\
\text { day) consumption (days } \\
\text { per month) }\end{array}$ & $1.3 \pm 2.5(0-25)$ & $2.6 \pm 4.0(0-25)$ & $\begin{array}{l}\mathrm{NnC} 14.3(78) \\
\mathrm{PC} 1.5(8)\end{array}$ & $\begin{array}{l}\text { NC } 37.2(203) \\
\text { PnC } 47.1(257)\end{array}$ \\
\hline $\begin{array}{l}\text { Tobacco consumption } \\
\text { (units per day) }\end{array}$ & $1.1 \pm 3.0(0-25)$ & $1.7 \pm 3.9(0-25)$ & $\begin{array}{c}\mathrm{NnC} 6.8(37) \\
\mathrm{PC} 0.5(3)\end{array}$ & $\begin{array}{c}\text { NC } 15.4(84) \\
\text { PnC } 77.3(422)\end{array}$ \\
\hline $\begin{array}{l}\text { Caffeine consumption } \\
\text { (drinks per day) }\end{array}$ & $0.8 \pm 1.0(0-8)$ & $1.3 \pm 1.3(0-7)$ & $\begin{array}{l}\mathrm{NnC} 2.4(13) \\
\mathrm{PC} 30.8(168)\end{array}$ & $\begin{array}{c}\text { NC } 12.3(67) \\
\text { PnC } 54.6(298)\end{array}$ \\
\hline $\begin{array}{l}\text { Taking medication with- } \\
\text { out professional advice }\end{array}$ & $\begin{array}{l}\text { Never: } 34.2(187) \\
\text { Rare: } 47.1(257) \\
\text { Occas: } 16.1(88) \\
\text { Often: } 2.6(14)\end{array}$ & $\begin{array}{l}\text { Never: } 33.9(185) \\
\text { Rare: } 44.0(240) \\
\text { Occas: } 17.9(98) \\
\text { Often: } 4.2(23)\end{array}$ & $\mathrm{NnC} 16.7$ (91) & $\begin{array}{c}\text { NC } 5.5(30) \\
\text { PnC } 76.6(418)\end{array}$ \\
\hline $\begin{array}{l}\text { Frequency of condom use } \\
\text { (per sexual intercourse) }\end{array}$ & $\begin{array}{l}\text { Abstin: } 19.6(107) \\
\text { Rare: } 20.1(110) \\
\text { Often: } 12.5(68) \\
\text { Always: } 47.8(261)\end{array}$ & $\begin{array}{c}\text { Abstin: } 19.2(105) \\
\text { Rare: } 19.2(105) \\
\text { Often: } 12.3(67) \\
\text { Always: } 49.3 \\
(269) \\
\end{array}$ & $\mathrm{NnC}^{*} 28.6(156)$ & $\begin{array}{l}\mathrm{NC}^{*} 2.9(16) \\
\mathrm{PnC}^{*} 66.1 \\
(361)\end{array}$ \\
\hline Health monitoring & & & & \\
\hline
\end{tabular}




\begin{tabular}{|c|c|c|c|c|}
\hline \multirow{3}{*}{$\mathrm{HBA}$} & \multicolumn{2}{|c|}{ Prevalence of HBA $(N=546)$} & \multirow{2}{*}{\multicolumn{2}{|c|}{$\begin{array}{l}\text { Direction of possible changes in } \\
\qquad \operatorname{HBA}(N=546)\end{array}$}} \\
\hline & \multicolumn{2}{|c|}{$M \pm S D($ Min-Max $)$ or $\%(n)$} & & \\
\hline & Before university & In university & \multirow[b]{4}{*}{ PC $7.5(41)$} & \multirow{4}{*}{$\begin{array}{c}\text { NC } 9.4(51) \\
\text { PnC } 57.5(314)\end{array}$} \\
\hline \multirow{3}{*}{$\begin{array}{l}\text { Frequency of health moni- } \\
\text { toring (per year) }\end{array}$} & Never: 0.7 (4) & Never: 0.5 (3) & & \\
\hline & Occas: 46.7 (255) & Occas: $42.1(230)$ & & \\
\hline & Often: 24.9 (136) & Often: $22.9(125)$ & & \\
\hline Lifestyle (general measure) & $10.3 \pm 1.6(5-13)$ & $9.1 \pm 2.0(0-13)$ & & \\
\hline
\end{tabular}

* Answers were analysed according to whether or not students had sexual intercourse and multiple sexual partners.

Statistically significant $(p<.01$ or $p<.05)$ differences between average values of each $\mathrm{HBA}$ and lifestyle, before and after entering university, were found (except for illicit drugs consumption), with students giving lower ratings after transition in eating behaviour, sleepwake pattern, physical/sports activity pattern, health monitoring and lifestyle (general measure) and higher ratings in psychoactive substances consumption, self-medication and safe sexual behaviour.

As to freshmen's perception of the impact of these possible changes, students admitted that lifestyle alterations had a negative impact $(n=249,45.6 \%)$ or no impact at all $(n=$ $238,43.6 \%)$ in their general health condition, no impact at all $(n=291,53.3 \%)$ or a positive impact $(n=129,23.6 \%)$ in their adaptation process and, at last, no impact at all $(n=268,49.1 \%)$ or a negative impact $(n=212,39.8 \%)$ in their academic performance. Only $36.8 \%$ of the respondents $(n=201)$ would like to change something in their lifestyle and almost half of them $(n=95,47.2 \%)$ wanted to start or to increase physical/sports activity practice.

Table 2 presents information about sample's actual general health condition, academic performance and quality of the adaptation process.

Table 2 - Descriptive statistics of actual general health condition and academic success

\begin{tabular}{|c|c|c|c|c|}
\hline \multicolumn{2}{|c|}{ Variables } & \multicolumn{2}{|c|}{$\%(n)$} & $M \pm S D($ Min-Max $)$ \\
\hline \multicolumn{2}{|c|}{$\begin{array}{l}\text { Physical health condition } \\
\qquad(n=544)\end{array}$} & $\begin{array}{l}1=\text { Bad } 4.6(25) \\
2=\text { Fair } 26.1(142) \\
3=\text { Good } 41.0(223)\end{array}$ & $\begin{array}{l}4=\text { Very good } 22.8(124) \\
5=\text { Excellent } 5.5(30)\end{array}$ & $3.0 \pm 1.0(1.0-5.0)$ \\
\hline \multicolumn{2}{|c|}{$\begin{array}{l}\text { Mental health condition } \\
\qquad(n=544)\end{array}$} & $\begin{array}{l}1=\text { Bad } 5.0(27) \\
2=\text { Fair } 18.0(98) \\
3=\text { Good } 30.5(166)\end{array}$ & $\begin{array}{l}4=\text { Very good } 31.4(171) \\
5=\text { Excellent } 15.1(82)\end{array}$ & $3.3 \pm 1.1(1.0-5.0)$ \\
\hline \multicolumn{2}{|c|}{$\begin{array}{l}\text { Academic performance } \\
\qquad(n=546)\end{array}$} & & & $10.7 \pm 4.2(0-18.5)$ \\
\hline $\begin{array}{l}\text { Quality of the } \\
\text { adaptation process }\end{array}$ & $\begin{array}{l}\text { Personal } \\
\text { Social } \\
\text { Vocational }\end{array}$ & & & $\begin{array}{l}3.5 \pm 0.8(1.4-5.0) \\
3.8 \pm 0.7(1.2-5.0) \\
3.9 \pm 0.7(1.1-5.0)\end{array}$ \\
\hline$(n=546)$ & $\begin{array}{l}\text { Learning } \\
\text { Institutional }\end{array}$ & & & $\begin{array}{l}3.2 \pm 0.6(1.5-4.9) \\
3.9 \pm 0.6(1.6-5.0)\end{array}$ \\
\hline
\end{tabular}


Results of Spearman's coefficient calculation revealed statistically significant $(p<.01$ and $p<.05$ ) associations (which varied from low to moderate strength) between lifestyle (its general measure and some of HBA considered) and actual general health condition or academic success indicators. Here is some relevant data: (a) the general measure of lifestyle was positively associated with physical health condition $(\rho=.25, p<.01)$, mental health condition $(\rho=.23, p<.01)$, academic performance $(\rho=.26, p<.01)$ and personal $(\rho=.25$, $p<.01)$, learning $(\rho=.25, p<.01)$ and vocational $(\rho=.12, p<.01)$ experiences; (b) the quality of sleep was positively related with all indicators of actual general health condition and academic success $(.13 \leq \rho \leq .36, p<.01)$, (c) the practice of physical/sports activity was positively associated physical health condition perception $(\rho=.30, p<.01)$, (d) the consumption of excessive alcohol was negatively associated with learning experiences $(\rho=$ $-.13, p<.01)$ and academic performance $(\rho=-.10, p<.05)$, but positively related with social experience $(\rho=.18, p<.01)$; and (e) the consumption of tobacco was negatively associated with academic performance $(\rho=-.25, p<.01)$, learning experience $(\rho=-.17, p<.01)$ and mental health condition $(\rho=-.13, p<.01)$.

\section{Conclusions \& Discussion}

Although the prevalence of HBA has changed (probably, as consequence of the adaptation process to multiple changes and challenges) and lifestyle global measure has decreased with transition to higher education, most of the students have changed to or maintained a healthy lifestyle, except for excessive alcohol consumption and physical/sports activity practice. Despite the considerable number of students who felt a negative impact of those lifestyle alterations on their general health condition and academic performance, only a few would like to change something, such as (to start or to increase) physical/sports activity practice. This discrepancy may be due to: (1) perceived invulnerability to diseases in young adults (more than $69 \%$ of the sample classified its general health condition as good, very good or excellent), (2) existence of benefits (e.g., sense of belonging increasing) in expressing negative HBA such as psychoactive substances use or sleep deprivation required by academic parties (in this study, the consumption of excessive alcohol was results positively related with social experience) and (3) the complex mechanisms involved in intention (to change HBA) formation, as explained by several theoretical models. Students' choice of physical/sports activity practice wasn't surprising given (1) the large percentage of practitioners $(77.3 \%)$ that changed for (or remained in) insufficient levels of practice and (2) the growing demand for physical/sports activity programs (a new social phenomenon) owing to several reasons (aesthetic, performance, health-related, etc.).

Most of the associations found between lifestyle and general health condition or academic success indicators are consistent with the literature: in general, healthier lifestyles (with more positive HBA) provide higher levels of perceived general health condition and academic performance and vice versa. However, in this sample, the practice of physical/ sports activity seems to play an important role in physical health condition, which is no extensible to academic performance (probably due to time management difficulties), as well as the excessive alcohol use seems to be relevant in social experiences quality (and vice versa), despite collateral damage. These results provide important information for planning an intervention project to promote health and academic success in higher education specific 
context: work out the meaning of some negative HBA and take into consideration sample's intention about HBA changes.

\section{REFERENCES}

Almeida, L., SoAres, A., \& Ferreira, J. (2000). Transição e adaptação à universidade: apresentação do Questionário de Vivências Académicas (QVA). Psicologia, 14(2), 189-208.

DeBerard, M., Spielmans, G., \& Julka, D. (2004). Predictors of academic achievement and retention among college. College Student Journal, 38(1), 66-80.

Dusselier, L., Dunn, B.,Wang, Y., Shelley II, M., \& Whalen, D. (2005). Personal, health, academic, and environmental predictors of stress for residence hall students. Journal of American College Health, 54(1), 15-24.

Elias, A., Azevedo, V., \& Maia, A. (2009). Saúde e rendimento académico nos estudantes da Universidade do Minho: percepção de áreas problemáticas. In Colectivo (Eds.), Actas do Congresso Saúde e Qualidade de Vida (pp. 292-302). Porto: Escola Superior de Enfermagem do Porto.

Fleck, M. (2008). A avaliação de qualidade de vida: Guia para profissionais de saúde. Porto Alegre: Artmed.

Grant, N., Wardle, J., \& Steptoe, A. (2009). The relationship between life satisfaction and health behavior: A cross-cultural analysis of young adults. International Journal of Behavioral Medicine, 16, 259-268.

Ogden, J. (2004). Psicologia da saúde (2 $2^{\text {nd }}$ ed). Lisboa: Climepsi.

Pinheiro, M. (2004). O desenvolvimento da transição para o ensino superior: O princípio depois de um fim. Aprender, 29, 9-20.

Pittman, L., \& Richmond, A. (2008). University belonging, friendship quality, and psychological adjustment during the transition to college. The Journal of Experimental Education, 76(4), 343$-361$.

Precioso, J. (2004). Educação para a saúde na universidade: um estudo realizado em alunos da Universidade do Minho. Revista Electrónica de Enseñanza de las Ciencias, 2(3), 161-170. Retrieved from http://reec.uvigo.es/volumenes/volumen3/Numero2/ART3_Vol3_N2.pdf.

RaYle, A., \& Chung, K. (2008). Revisiting first-year college student's mattering: social support, academic stress, and the mattering experience. J. College Student Retention, 9(1), 21-37.

Reich, W., Harber, K., \& Siegel, H. (2008). Self-structure and well-being in life transitions. Self and Identity, 7, 129-150.

SeAbra, A. (2007). Queixas de saúde subjectivas e preocupaçôes modernas de saúde: Um estudo comparativo entre alunos de diferentes licenciaturas (dissertação de mestrado). Braga: Escola de Psicologia da Universidade do Minho.

Seco, G., Casimiro, M., Pereira, M., Dias, M., \& Custódio, S. (2005). Para uma abordagem psicológica da transição do ensino secundário para o ensino superior: pontes e alçapões. Leiria: Instituto Politécnico de Leiria.

Soares, A. M., Pereira, M. D., Canavarro, J. M. (in press). Transição para o ensino superior: estilo de vida, estado de saúde e qualidade de vida do primeiranista. Psicologia, Saúde \& Doenças.

Trockel, M. T., Barnes, M. D., \& Egget, D. L. (2000). Health-related variables and academic performance among first-year college students: Implications for sleep and other behaviors. Journal of American College Health, 49(3), 125. 
Upcraft, M., Gardner, J., Barefoot, B., \& Associados (2005). Challenging and supporting the first-year student: A handbook for improving the first year of college. EUA: John Wiley \& Sons, Inc. VAeZ, M., \& LAflamme, L.(2003). Health behaviors, self-rated health, and quality of life: A study among first-year Swedish university students. Journal of American College Health, 51(4), 156-162. 